\title{
Success Factors in Western and Chinese Born Global Companies
}

\author{
Svante Andersson $1^{*}$, Mike Danilovic ${ }^{1,2^{*}}$, Hanjun Huang ${ }^{*}$ \\ ${ }^{1}$ Centre of Innovation, Entrepreneurship and Learning Research (CIEL), Halmstad University, Halmstad, Sweden \\ ${ }^{2}$ Shanghai Dianji University, Shanghai, China \\ Email: " mike.danilovic@hh.se
}

Received 15 February 2015; accepted 2 March 2015; published 5 March 2015

Copyright (C) 2015 by authors and Scientific Research Publishing Inc.

This work is licensed under the Creative Commons Attribution International License (CC BY).

http://creativecommons.org/licenses/by/4.0/

(c) (i) Open Access

\section{Abstract}

Born Global firms are becoming increasingly more important in terms of internationalization, innovation, ability to grow and providing employment. Most of the previous research about Born Globals is done in North America, Europe or Australia, all these being developed industrialized countries but not developing countries or emerging markets. However, the emerging markets in general, and the Chinese in particular, have become very important for the world economy. Our aim is to investigate the differences between Western literature and literature from emerging markets, regarding internationalization process of Born Global firms. We also aim to discuss the various success factors, which underlie Born Globals' internationalization process, particularly focusing on Born Globals firms in the China. Our methodology in this research has been literature review and interviews with Chinese CEOs of Born Global firms. However, this paper is only based on the litterateur part of our research. Our analysis shows that most of the Chinese Born Globals publications about the internationalization success factors are based on the Western literature and use them as the theoretical platform in the design of their own research strategy and research questions design. The consequence of this observation is important as it indicates that Chinese researchers are reproducing research under different contextual and situational conditions that might lead to unclear conclusions or maybe even wrong conclusions. Furthermore, compared to most Western Born Global companies, which treat innovation as core competence, the innovation culture becomes one of the biggest weaknesses of Chinese manufacturing Born Globals' internationalization. China has special economic environment. Chinese manufacturing Born Globals not only need to follow the market but also the government policies, since the government greatly influences the industries and the whole economy. To foreign investors who want to exploit Chinese market, they also should take Chinese economic background and government policies into consideration. One important aspect of Chinese born Globals, neglected in previous research on Born Globals, that has been identified in our research, is the critical success factor of Chinese manufac-

\footnotetext{
*The authors have equal authorship.

${ }^{\#}$ Corresponding author.
} 
turing Born Globals-the political and economic background and the role of the Chinese Government in the transformation process of Chinese business life, and the Guanxi network.

\author{
Keywords
}

Born Global Firms, Internationalization, China

\title{
1. Introduction
}

With the emerging and development of global economic integration, more and more companies go abroad to seek international opportunities and compete on international markets. Some new ventures, already from inception, start to allocate resources and sell products on an international arena. These new ventures called as Born Global firms are becoming increasingly more important in terms of, for example, internationalization, innovation, ability to grow and providing employment. Usually, Born Global companies (in short also called "Born Globals") are characterized by unique products, which are targeted to different nichemarkets (i.e. the markets on which specific products are focused) [1]. The unique products are created by innovative skills and capability to identify specific customer demands and market opportunity. The typical Born Global companies usually exist in high-tech industries. However, Born Global firms are also found in mature and low-tech markets [2]-[4]. Firms in small nations show more tendencies to become Born Global companies because of the limited market opportunities of their home countries [5].

Rapid but not gradual internationalization process of a Born Global firm is a characteristic, which seems to be the most obvious difference from how the traditional "stage model or the Uppsala Model", based on research of larger and more mature firms, explains a firm's internationalization process. According to the "Uppsala Model", internationalization is a sequence of a series of incremental decisions and also a gradual process with the accumulation of experiential knowledge of foreign markets and operation [6] [7]. Since knowledge of Born Global companies' internationalization process contradicts with the one explained by the Uppsala Model, some scholars have raised serious doubt of Uppsala Model's validity and to which extend those old models can be helpful in understanding modern empirical phenomena and exploring the concepts of Born Globals [8]-[12]. However, because of the complex nature of the Born Global phenomenon, comprehensive theoretical explanations and models of Born Globals' internationalization process are still lacking [9] [13] [14].

The findings in the extant literature so far have shown that there are many factors influencing the Born Global companies' internationalization. The growth of a Born Global is clearly associated with high innovative skill [11] [13]. The geographical location of a Born Globals' activities is determined by the founders' and partners' previous experience as well as economic capability or customer related factors. Also Born Globals rely more often on complementary competencies sourced from other firms; in their distribution channels they rely more often on hybrid structures such as network partners, joint ventures [11] [15]. In Andersson and Wictor's study [2], they emphasize the factors entrepreneurs, industry, globalization and networks and try to establish a conceptual framework to explain the internationalization of Born Global companies. Most of the previous research about Born Globals is done in North America, Europe or Australia, all these being developed industrialized countries but not developing countries or emerging markets. However, Andersson, Eriksson and Lundmark [5] state that literature should be complemented with country-specific studies of Born Globals. Through their research, Andersson et al., [5] found out that the internationalization of Malaysian furniture firms was rapid, but did not suit the explanation of the internationalization processes of firms as some received models (e.g. the stage model) offer.

\subsection{The Aim of This Research}

Following the above discussion this study's aims is to investigate the differences between Western literature and literature from emerging markets, when it comes to internationalization process of Born Global firms. We also aim to discuss the various success factors, which underlie Born Global's internationalization process, particularly focusing on Born Globals firms in emerging markets. For many years we have seen that China and Chinese 
firms have been successful on the global arena. We have reasons to believe that those Chinese firms in the future might have an important role to play in the global economy and therefore we should study Chinese Born Globals in order to understand how Chinese Born Globals act, their internationalization processes etc. Hence, the present study focuses on the experiences of Born Global firms in China, an emerging market whose unique characteristics may impact on the emergence and internationalization of Born Globals from that market.

\subsection{Outline of This Paper}

In the next section, methodology, which is employed for the present study is briefly discussed. This is followed by an introduction of the Born Global concept and the emerging market context used in this study; here, China as our setting is introduced. A review of both the literature on the internationalization processes of Born Globals firms from both Western countries and China follows. Thereafter, some successful factors underlying Born Global firms' internationalization will be identified, categorized, and build different themes out of the categories identified. Based on the themes developed, we build our conceptual framework, which is considered useful to help us understand success factors associated with Chinese and Western Born Globals' internationalization processes. Finally, conclusion and some implications of the present study are presented.

\section{Methodology}

Since there is scanty literature on the phenomenon "Born Globals" from settings other than the Western Industrialized countries, an explanatory research based solely on insights drawn from extant literature is employed. An exploratory research, as asserted by Malhorta [16], serves as a means to help acquire useful information or knowledge about a subject area, which virtually under-researched. By drawing on secondary sources, we endeavor to illuminate, first, the extent to which "Western Born Globals" and Born Globals from other settings, outside the Western countries, are similar when it comes to their efforts to internationalize their businesses rapidly. Secondly, we explore knowledge regarding the extent to which they show differences in their internationalization processes, differences that can stem from firm-specific factors and environmental-specific factors.

The analysis and/or discussions of the above two aspects will enable us to use that knowledge to attempt to build a comprehensive model of the internationalization of a "Born Global" firm. This need of a comprehensive theoretical explanations and/or models of Born Global's internationalization process has been pointed out in the literature as lacking [9] [13] [14]. Hence, our contribution will be to complement the existing literature by offering not only a deeper understanding of "Born Global" firms' internationalization processes, but also a model that may aid our understanding of internationalization of "Born Global" firms where firm-specific factors and environmental-specific factors do play important role. This use of secondary sources for our present study is consistent with what Gummesson [17] advises. For Gummesson [17], one burdensome task with all research is not to collect or to generate more data, but to interpret and combine what is already there and make some sense out of it. We try to make the most out of the insights we can get from the extant literature to address the phenomenon under study.

\section{Literature Review—State of the Art on Born Globals}

\subsection{Characteristics of Born Global}

In the study of Australian companies, McKinsey and Co. [18] mentioned that firstly unlike the traditional companies, the Born Globals do not see foreign markets as simple adjuncts to the domestic market but they view the world as its marketplace since its inception; secondly Born Globals begin to export one or several products within 2 years after they establish their business; and their exports make at least about a quarter of total sales; thirdly Born Globals tend to be small manufacturers with a significant breakthrough in some process or technology and majority of them are formed by active entrepreneurs, which may have a unique idea or a new way of doing business; fourthly the products sold by Born Globals typically involve substantial value added and the majority of such products may be intended for industrial use. Rasmussen and Madsen [19] found that in Australia there are several Born Globals, which are high-tech firms; and the typical firms use well-known technology. They usually standardize production and marketing in a global niche instead of developing customized products, experiencing higher growth rates than other industries. They are said to have a large growth in their exports compared to their home-market sales. 
Andersson and Wictor [2] indicated that Born Globals in Sweden are not only found in high-technology industries, but also within niches in mature industries. A survey of the Born Globals in Denmark showed that almost all of the firms consider their competitive advantage to be built on a higher quality and service than their competitors. Most of them produce standardized products and operate in a highly specialized niche. In fact most of them are not high-tech products [19].

\subsection{Born Globals in China}

After about 30 years "Closed-door Policy”, China launched its unprecedented "Reform and Opening-up Policy” in 1978. The reform involved almost all aspects of the society and the most pioneering creation was in the economy. The Chinese government changed the "Planned Economy" into market economy. Due to the nature of its socialist lineage, the Chinese market economy is quite different from the Western market economy, which is free-market oriented. The Chinese new economic system is called the "Socialist Market Economy", which is affected by the government to a large extend. From 1979 to 1984, the Chinese government decided to open three areas as special economic zones and 14 port cities to the world. These zones and cities cover almost the whole east coast line of China and become the earliest opening areas. Supported by determined government, these areas get more resources to develop infrastructures and enjoy a lot of preferential policies. The tax free or tax rebate policies as well as cheaper capital and labor prices attracted more and more foreign investors to come to China to establish manufacturing companies. Having been restricted for a long time, Chinese people began to have open mind and started business with full passion. Affected by the investment flow from abroad, going to international market also arose among the domestic companies or in the specific areas such as Zhejiang Province, which has thousand years of business cultural tradition. From then on, the boom of export-orientated economy started in China and became the main driving force of China's national economy until now [20]. Under this economic context, a lot of Chinese manufacturing Born Global companies emerge and develop. Most of them are located in the developed areas of China and cover both high-tech and traditional industries. With the rapid growth of China's economy, many companies have the situation to achieve fast internationalization. Although many Chinese Born Globals without famous brands and may not be known to the public do still have incredible internationalization speed [21].

According to Li and Zhou's [22] research on four Chinese Born Global companies, majority of these companies are engaged in traditional manufacturing industries and traditional export business, and their profit-orientated principles mostly influence their choices of markets and their internationalization process. It is quite different from Madsen and Servais's [11] opinion. Thus, Born Globals from smaller nations have various products, while Born Globals from large nations are limited to high-tech products. About the internationalization process theories, mixed and improved conceptual approaches toward a more holistic understanding of Born Global internationalization process are needed [23]. A lot of small or medium sized export-orientated enterprises become the main power of China's export economy. Many of these manufacturing enterprises can be considered as Born Globals [21] [22]. It arouses our interest to investigate the Chinese manufacturing Born Globals' internationalization process.

There are large amount of existing theories about the influencing factors of Born Global companies' internationalization, for example, entrepreneur, network, industry, knowledge or experience [2] [11] [13]. Due to the special economic or market environment of China, influence of some factors, according to former theories may not be significant; but some other factors, which have not been noticed by Western researchers, may play important roles. The Chinese socialist market economy grants the government more influence on business than other countries. The government is described by both domestic and foreign enterprises as "the biggest boss" in China. It may also be essential factor worth to be researched. Furthermore, the specific business culture in China as we mentioned also affects the way Chinese Born Globals do their international business as well as their successful internationalization. In Chinese business culture, the term for network or relationship is “Guanxi”. It means a special relationship between individuals, which enables them to make unlimited demands on each other [24]. Different from the definition of network in Western, Guanxi is a more utilitarian principle than emotional, which is based on family or friendship with overtones of unlimited exchange of favors [25]. Guanxi pervades the whole Chinese business process not only the relationship with business partners, but also with Chinese bureaucracy. Actually in China, some officials are involved into business so that Guanxi can facilitate some actions, which are inhibited by Chinese government. It is a very typical business culture in China which necessary 
to enterprises to learn. In additional, decisions are made from top to bottom in Chinese system [25] which means the government and entrepreneurs have superior power and influence.

Highlighting the importance of family is another aspect of Chinese culture. Sometimes, in international business, we can see the Chinese loyalty to family extended to the loyalty to country because country is the bigger family in Chinese culture. The loyalty of the overseas Chinese to their homeland is reflected in their investment. About 70\% of the Chinese capital inflow comes from the overseas Chinese who mainly come from Hong Kong, Fujian and Singapore [26]. Ye [27] finds that the industry cluster, which provides resources such as information, capital and human resource through network in China, can greatly affect the internationalization of Born Globals. In China, most of the industry clusters concentrate in areas, which have long business history and strong business culture for example, Zhejiang Province. The goods manufacturing and business in Zhejiang was prosperous in ancient China and due to the geographic location, the people in Zhejiang started international handcraft goods trade with Japan or Britain in Qing dynasty about 100 years ago. Flexible thinking, the sensitivity of market opportunities and adapting to changing market conditions become main characters of Zhejiang businessmen [28]. Combined with the Guanxi between each other, the Zhejiang businessmen have huge business network not only in local areas but also on a worldwide scale.

Overall, on the base of both Western and Chinese relevant theories, we find that specific kind of Chinese manufacturing Born Globals grow under the Chinese political and economic background. These political and economic factors combined with Chinese business culture make the Chinese Born Globals quite different from the Born Globals showed in Western literatures. Consequently, we consider the Chinese manufacturing Born Globals and their internationalization as an interesting topic for our research.

\subsection{Success Factors Underlying Born Globals' Internationalization}

Oviatt and McDougall [29] identify 7 successful characteristics of Born Globals: global vision [30] from inception, managers with international experience [31], international business network [2], exploited preemptive technology and marketing, unique intangible asset, closely linked product or service extension, closely coordinated worldwide organizations. Knight and Cavusgil [32] highlight the critical influential factors, namely, innovation culture, foreign market knowledge and organizational capability. Other factors are, for example, awareness of foreign markets opportunities [14], entrepreneurial cognition [33]-[35], industry condition [36]-[39], [3] [4] and geographic location [40].

Chinese scholars [34] [41] point out the entrepreneur's spirit and international network as the roots of Chinese Born Global companies' competitive advantage; [22] find that the entrepreneur's experience, local network, the international level of the industry and government policies are the main factors accelerating the development of Chinese Born Global companies. There are also many researchers, which emphasize the entrepreneur's abilities of innovation, risk taken, identifying opportunities, adapting to changing environment and combining the resources [34] [42]. [27] points out the positive relationship between industry cluster in Zhejiang Province and the development of Born Global companies in these areas.

These success factors also are collected into comprehensive influential factor models by some other researchers. Based on the organizational, strategic management, resource and entrepreneurship theories, [43] establish a complete model to explain the force factors of internationalization speed, degree and scope. They sum up these factors into organizational factors, which are top management team characteristics [29] [44], firm unique resource, firm specific variables such as age, scale and location, growth orientation, financial strength, product and service [32] external environment contains national culture, growth opportunities, profitability of industry and economies of scale; strategic factors comprised by generic strategy such as low-cost or differentiation competitive strategy, functional strategy such as production or marketing strategy, entry strategy [44] [45]. [46] also categorize Born Global's internationalization driving force into four categories: entrepreneurial specific factors which are made up of entrepreneur's foreign language, education, international and prior working experience; business specific mainly means focalization of strategy; location specific contains clusters and districts; network specific includes formal agreements, social relationship and knowledge sharing at international level. By analyzing data from 144 Italian Born Global companies, they find entrepreneurial specific and business specific factors positively and strongly affect Born Global's internationalization while the influential relationship of other two specifics are not clear. At the same time, the similar integrative models also show in Chinese relevant research area. 
[47] build a model, combining the factors of entrepreneur's international cognition, experience, international network resources and the choice of target market. With more theoretical base, Zhu [21] designs a model, which contains the original influential factors of entrepreneur's spirit and enterprise's social capital and then these two factors affect the knowledge learning process of Born Globals and finally work on the degree and scale of internationalization process. In all, we can summarize these success factors into a table to see the different aspects, which Western and Chinese scholars focus on.

After describing so many Born Global's success factors both from traditional Western theories and Chinese related theories, we find some common aspects of them and summarize them into several themes: entrepreneur's international vision, experience, knowledge, working experience, education background, ability and cognition; entrepreneur and enterprises' local and international network; organization's financial condition, innovation culture, unique resource, products or service, competitive and market entry strategies; the external industry condition, geographic location and government policies.

In order to see the commonality and the difference between Western and Chinese Born Globals in this academic research field, we make a table as follows to compare them. From Table 1, firstly, we can see that both Western and Chinese scholars pay much attention to the factor entrepreneurs themselves; and the articles' mention of each specific item is quite the same between Western and Chinese researches. It reflects that no matter the setting, in Western and in China, the entrepreneur is always one of the most important success factors; this stems from the Born Global's small or medium size and the lack of comprehensive organizational structure.

Obviously, the difference mainly exists in the organizational factors. Chinese researchers do not emphasize organizational factors as much as Western researchers do. Among about 10 Chinese articles we have investigated, these is no one researchers discussing the factors such as innovation culture, product or service and competitive or market entry strategies. Due to the limited quantity of articles, we can also consider that Chinese researchers pay less attention to these factors. Here, we infer that it might be related to Chinese Born Global's specific characters. However, it could also be related to the fact that Chinese researchers overlook those aspects in their research or due to the methodological approaches chosen. Differences from the Western Born Global companies mostly exist in high-technology industries; Chinese Born Global companies are more concentrated in

Table 1. Success factors of born Global’s internationalization.

\begin{tabular}{lcc}
\hline Success Factors & Western Literature & Chinese Literature \\
\hline Entrepreneur's International Vision & {$[14][29][30]$} & {$[47]$} \\
Entrepreneur's International Experience & {$[29][31][43][44][46]$} & {$[22][47]$} \\
Entrepreneur's International Knowledge & {$[32]$} & {$[35]$} \\
Entrepreneur's Working Experience & {$[46]$} & {$[22]$} \\
Entrepreneur's Education & {$[46]$} & {$[35]$} \\
Entrepreneur's Ability & {$[30]$} & {$[34][42]$} \\
Entrepreneurial Cognition & {$[2][29][31][46]$} & {$[41][47]$} \\
International Network & {$[31]$} & {$[22]$} \\
Local Network & {$[43]$} & {$[48]$} \\
Financial Condition & {$[32]$} & {$[41][49]$} \\
Innovation Culture & {$[29][43]$} & {$[22]$} \\
Unique Resource & {$[29][32]$} & {$[29][43]-[45]$} \\
Product or Service & {$[3][4][36]-[39][43]$} & {$[40][43][46]$} \\
Competitive or Market Entry Strategy & & {$[41]$} \\
Industry Condition & {$[43]$} \\
Geographic Location & & {$[22]$} \\
Government Policies & & \\
\hline
\end{tabular}


traditional industries, which do not require high knowledge intensity. So the innovation culture and the products having niche market are not so important in Chinese Born Global companies. Quite interestingly, government policies are rarely seen in Western research but we find that these seem to be important factor presented in Chinese articles. Though only one Chinese article mentions the government policies, we can still perceive that under Chinese special economic context, the policies from government can greatly affect the industries.

However, Chinese government is trying to change the Government-Dominated economic image, so the frequency of policies in academic articles is not as high as before. Furthermore, comparing the amount of articles, we find there are more Western articles, which mention industry condition and geographic location than Chinese articles.

Most of the Chinese scholars cite the Western literatures and then use these theories to test the Chinese Born Global cases to see whether they fit Chinese Born Globals' practice or not. One important explanation to these observations is related to the methodological limitations of many Chinese studies. These studies are survey based and therefore based on predefined questions and answers. We have not found Chinese business research based on Grounded theory approach or explorative that is not based on Western research, Western findings and Western way of thinking. During this research process, they may get some conclusion, which is more suitable for the Chinese Born Globals' situation. We can say that Chinese Born Globals literature is based on Western literature and rarely with initiation and breakthrough findings that in a unique way explores the Chinese specific Born Globals internationalization processes.

We have identified important difference in the research strategies Western and Chinese scholars use. We see more case studies in Western research, while Chinese scholars more prefer to use quantitative and survey based research strategy. Among the above 10 Chinese articles, four of them are previous theory retrospection or argue from the pure theoretical perspective; four of the others use quantitative research strategy while the remaining two are qualitative case studies. Through case studies, Western scholars can get a deep understanding of these Born Globals' cases and can more easily answer the "How" and "Why" questions. Chinese scholars rely more on SPSS or literature reviews to analyze the empirical data and introduce the internationalization performance indicator such as Born Global's export percentage into the statistical analysis. From the result of the statistical analysis, they can get the degree of each factor's impact on Born Globals' internationalization. These Chinese scholars consider the result from the quantitative research is more valid and reliable.

There are consequences of such chosen research strategy and approach chosen by Chinese scholars. If the western literature is the role model and their research questions are based on the dominant writing in the western literature, which is based on western companies research, then the Chinese research might be more reproductive and not enough exploring the special Chinese's context, situation and factors that make Chinese Born Globals special and make it possible to identify discriminating factors compared to western research. This calls for review of research strategy and approach choses by Chinese researchers.

\section{Conceptual Framework}

Analyzing these success factors found in literature on Born Globals in the western and Chinese literature, we find they can be divided into four main categories: entrepreneurial perspective, organizational perspective, strategic perspective and external environmental perspective. Here we rearrange these factors under different items. Mainly based on Zahra and George's [43] influential factors model, we also absorb some ideas from other models mentioned above [2] [21] [46] [47] and then we rearrange success factors from Table 1, and establish a conceptual model (see Figure 1).

In Figure 1 we can see those four major aspects and major factors within each of those aspects that are important to understand Chinese Born Globals internationalization processes. We argue that entrepreneurial factors, organizational factors, strategic factors and external environment factors jointly affect Born Global's internationalization process.

\section{Description of the Conceptual Framework}

\section{Entrepreneurial Perspective}

Compare Table 1 and Figure 1: Keeping the item "international vision”, we add "entrepreneur's working experience" to the item "entrepreneur's international experience" because most of the working experience found in the literature reviews is international working experience. From the entrepreneur's perspective, we also com- 


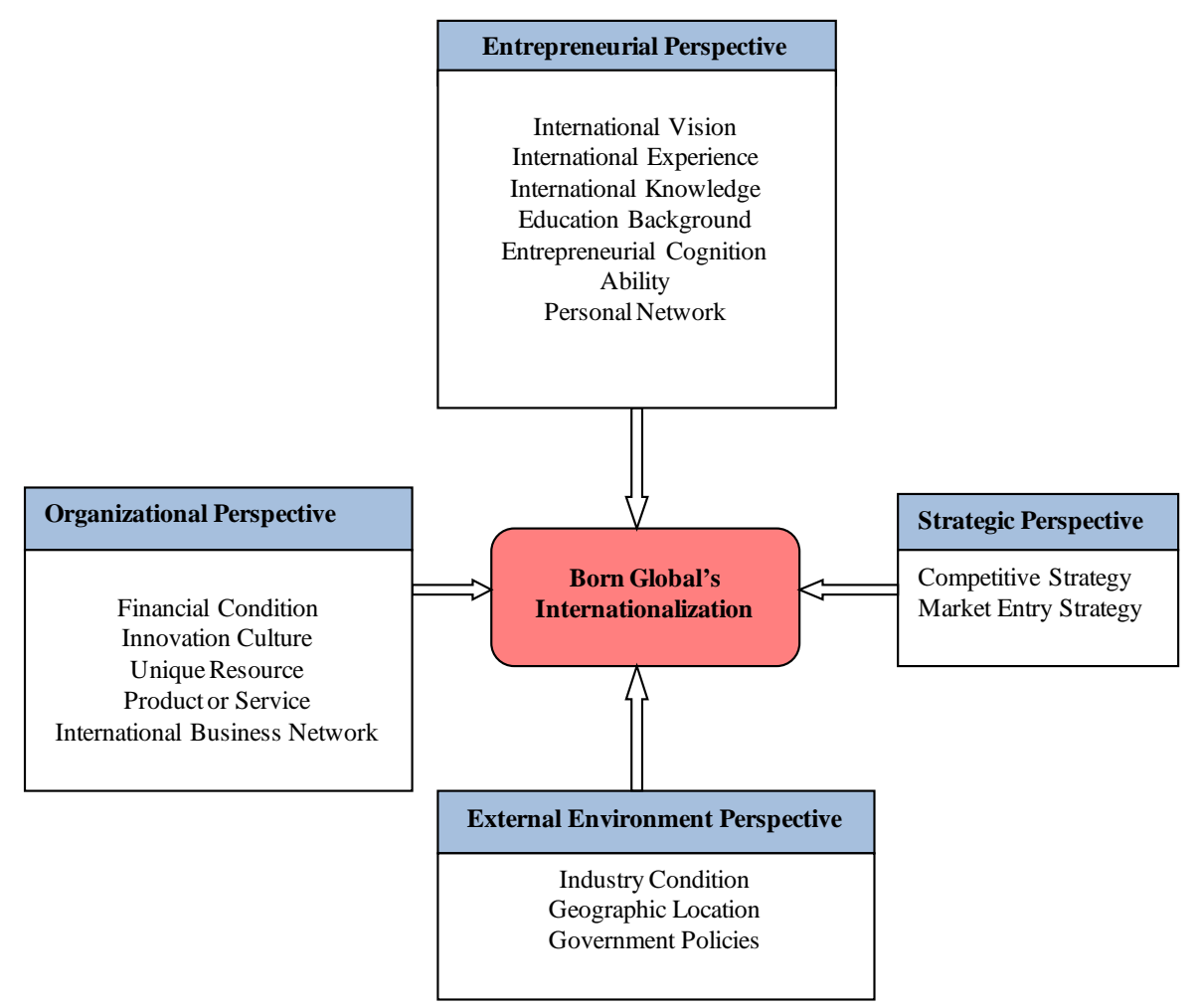

Figure 1. Success factors model of born Global's internationalization.

bine the entrepreneur's personal "international network" and "local network" into "entrepreneur's personal network". Here, we consider company's international network as "international business network" because most of company's networks treated in the literature are related with its business partners. Similarly, we divide "competitive or market entry strategies" into "competitive strategy" and "market entry strategy".

There are a lot of definitions of entrepreneurs. Here, we use the definition that Born Global entrepreneurs are the people who carry out entrepreneurial actions [10]. Born Global founders or managers are included in this definition.

1) Entrepreneur's International Vision

As [29] said, global vision is the most important founders' characteristic associated with success because they do not bind their business thinking to a single country or culture. These entrepreneurs treat the global market as their target market and try to seek competitive advantage from the inceptions of their business [30]. [47] found that all Chinese Born Global entrepreneurs have global visions, strong desire to compete in international markets, and seek international opportunities actively.

2) International Knowledge and Experience

We discuss knowledge and experience as one aspect of Born Global entrepreneurs' characteristics because we find many literature that consider that the international knowledge mainly comes from entrepreneur's international practical experience. During Born Global's internationalization, entrepreneurs' international knowledge such as how to get and use international relationships provides particular advantages because it increases the quality of organizational routines [32] [35]. [29] think that founder or manager's international experience is necessary to Born Global companies' internationalization. These experiences contain cross-border conduct, risk of exchange rate, communication skill and culture conflicts greatly reduce the international business risks and increase efficiency. Entrepreneurs' global vision is also, in some part emanating from their international knowledge and experience. According to Chen, Hu and Zhao's [47] research, the entrepreneurs with the experiences such as working experience in relevant industries, international companies, life experience abroad and international marketing experience can help these Born Global entrepreneurs start their business more easily and successfully. 
3) Education Background

Compare to international knowledge and experience, the influence from education background is not so strong. But, [46] point out that among the education background, the knowledge of foreign language is the most obvious fundamental precondition. As an aspect of entrepreneur's characteristics, [35] thinks the education background can, in some terms, affect entrepreneur's specific mind and thinking, something which then influence the choice of companies' strategies.

4) Entrepreneurial Cognition

Acedo and Jones [33] consider three concepts that make up entrepreneur's cognition. Through their research, they find international orientation leads to higher level of entrepreneur's proactivity and lower perception of risk; entrepreneur's tolerance of ambiguity can lower the risk and finally accelerates Born Global's internationalization. [34] considers the desire to success, the sensitivity of opportunities and the courage to overcome difficulties make up the basic requirements of Born Global entrepreneur's cognition. Similarly, [35] find entrepreneur's entrepreneurial cognition tightly related to entrepreneur's orientations of starting venture, international knowledge learning, risk taken ability and action.

5) Entrepreneur's Abilities

[34] establishes a complete model to test the influence that entrepreneur's abilities on Born Global companies' internationalization have. He finds that entrepreneur's innovative and risk-taken abilities affect Born Global's innovation and size; the ability of identifying and using opportunities help Born Globals to enter new markets faster; the ability to adapt to changing environment makes Born Globals survive in fierce international competition; efficiently combining the resources increasing Born Global's competitiveness; communication and coordination abilities make ensure sustainable development. Similarly, [30] also highlight the risk-taken ability.

6) Entrepreneur's Personal Network

[31] emphasizes the importance of Born Global entrepreneur's personal network. He points out that entrepreneurs with industry experience could use the contact to expand their own business and it is also helpful to find financial support and find strategic partners in foreign markets. [22] also acknowledge the function of personal network especially at the beginning of Born Global's internationalization.

Organizational Perspective

1) Financial Condition

There are not so many theories about the relationship between Born Global's internationalization and its financial condition. [43] mentioned in their research that the financial strength positively and/or significantly affects the speed and degree of international sales. Leverage is also positively associated with the degree of internationalization. The joint venture comprised by Born Globals and some large firms who possess adequate capital and advanced technology can accelerate Born Globals' internationalization through integration of these resources [48].

2) Innovation Culture

Innovation mainly comes from firm's internal R\&D based on the accumulated knowledge and imitated innovation from other firms [50]. Through their research, [32] concluded that strongly innovative culture of Born Global firms supports business by developing particular knowledge. These kinds of knowledge force the development of organizational capabilities and finally support the early internationalization of Born Global firms and their performance in international market. Furthermore, innovative activities support opening of new markets and reinvention of firm's operation.

3) Unique Resource

In a worldwide area, products or service are easily to be imitated, due to the few resource, Born Global companies must depend on some intangible resources such as unique knowledge to sustain competitive advantage [29] [41]. [43] not only state that firm's unique assets such as product innovativeness influence the internationalization process, but also they think reputation and networks of a Born Global company can significantly influence the speed and degree of internationalization. Except possessing the unique resources, [49] more highlights the seeking and integration of these unique resources.

4) Product or Service

Because of the limited resource of Born Global companies, they must use their unique resource which derived from original competitive advantage to continue the innovation of the product and service with extension [29]. [32] believe that technology competence, unique product development and product quality focus provide organizational activities related to R\&D, knowledge development, play an important role in positioning Born Glob- 
als for international success.

5) International Business Network

According to Oviatt and McDougall's [29] opinion, start-ups especially Born Globals, are more dependent on supportive international business network; they cannot survive without trusted and trusting financiers, suppliers and distributors. [46] proves that network, mainly the knowledge sharing at the international level with other firms, shows the positive association with Born Global's internationalization. The international business networks provide Born Global companies the necessary foreign market knowledge and experience, reduce the uncertainty and risk from the target market and make them get into international markets more easily [47].

Strategic Perspective

1) Competitive Strategy

Oviatt and McDougall's [29] find ways for Born Globals to overcome their inexperience and small size so as to use their competitive strategy: to be the first to market distinctively valuable product or service. The same opinion can also be seen from [43]; they think that Born Global's competitive strategies such as low-cost strategy and products differentiation strategy are positively related with internationalization because these strategies help firms to enter and occupy foreign market fast. Usually, these competitive advantages come from the intangible unique resources such as knowledge or human resource.

2) Market Entry Strategy

Market entry strategy is very important to Born Global companies. After comparing the domestic and international entrepreneurship, [45] finds that Born Globals try to seek, for example, market entry strategies for example developing and controlling numerous distribution channels to penetrate foreign markets. And these Born Globals' entry strategies are more various, aggressive and large scale across national borders. However, this opinion is different from Burgel and Murray et al. (1998)'s [44]. They think because of lack of necessary resource like network and capital, new start-ups tend to choose low-resource entry modes using, for example, intermediaries such as trade companies rather than exporting directly. They also find a positive relationship between the firm size and the dependence on intermediaries. We think that compared to other international firms, Born Globals are more active to carry diverse market entry strategies. However, at the beginning of their internationalization, they prefer low-resource market entry mode more.

External Environment Perspective

1) Industry Condition

Industry evolution influence firms' international strategies [36]. In mature industries, the rate of change is slower than in high-growth industries (Eisenhardt and Shoonhoven, 1990; Preece et al., 1998). The internationalized competition among some industries force firms move into foreign markets and a lot of international new ventures (Born Globals) exist in high-technology industry, which has more international opportunities [37]. Autio, Sapienza and Almeida's [38] research also supports this opinion because they find positively and significantly relationship between the industry's knowledge intensity, imitability and firm's international sales. They give their explanation that firms with highly imitable products or knowledge bases will accelerate their internationalization to avoid eroding this advantage. [39] systematically analyze the influence industry structure exert on international new venture's (Born Global) internationalization. They get the conclusion that: international new venture's internationalization more happens within the industry in its growth stage; the more competition in the industry the more firms tend to internationalize; international new venture more exist in high-technology industry; the greater the local industry internationalization and global integration the more international new ventures in this industry. However, according to [41], the intensity of knowledge more affect the high-technology industries while to the mature or declining industries, cost advantage and marketing skills are more important. Most studies on internationalization of firms have been done on high-tech industries and often it is taken for granted that here is a strong correlation between high tech industries and internationalization. However, Evers [3] found that internationalization in low-tech sectors were strongly influenced of industry factors. She concluded that a high degree of international demand and a global integration of the industry were crucial for the international development in the studied firms in a low-tech sector. Her study also showed a positive relationship between internationalization of local industry and emergence of INVs, which will be further discussed in next part. The entrepreneurs/managers in low-tech sectors did not have international experience but still were successful in their international ventures, which might indicate that international experience is not the only or most important managerial characteristic but a drive for growth and development is more important.

2) Geographic Location 
Here, we only discuss Born Global's location in industry cluster ${ }^{1}$ area. [40] confirm the positive relationship between industry clusterand Born Globals' internationalization. They find within the industry cluster that Born Global entrepreneurs are more conscious of international opportunities the firm themselves can share more information, opportunities through the network in the cluster and they can also get venture more easily. Similar conclusion also given by Chinese Master student [27]. After quantitative research on Chinese Born Global companies, he finds most of them come from some specific industry cluster area such as Zhegjiang Province or Zhujiang area. In the export-orientated economic environment, he concludes network-based knowledge learning and human resource movement as well as the infrastructure among the industry cluster greatly stimulates the internationalization of Born Global.

3) Government Policies

The government policies or support as one influential factor of Born Global's internationalization is rarely seen in western literatures. However, due to China's specific socialist market economy, government's impetus cannot be neglected. [22] argue that many Chinese local governments encourage the exportation of firm and policies such as export tax rebate and launching international exhibitions, which in some terms speed the internationalization of Chinese Born Global companies.

\section{Differences in Success Factors between Chinese and Western Studies of Born Globals}

From our literature review we can conclude that most factors explaining the prevalence of Born Global companies in China and Western literature are the same. However we can also conclude that some factors are different.

Among the entrepreneurial factors, we found entrepreneur's international knowledge and experience, entrepreneur's abilities and personal network. Different from the domestic business, the international market is more complex. The Born Global entrepreneurs with international knowledge and experience are more familiar with the international market and also know more about how to compete in it and get more necessary resource from it. As we argued before, because of the "top to bottom" decision-making pattern in Chinese business culture, the importance of entrepreneur in Chinese enterprises is more obvious which we can also see from the Chinese literature about the Born Global entrepreneur's abilities. Entrepreneur's network, especially the special Chinese network "Guanxi”, is essential for Chinese Born Globals to get vital resources. These make them become the key factors of our analysis. The reasons we ignore other factors are: we think once the entrepreneur decides to compete in international market, the international vision which means treating global market as target market and seeking competitive advantages on a global scale [30] is necessary to entrepreneurs no matter whether they have the international vision at beginning or not; most of the small or medium sized private companies' entrepreneurs in China have no high education background at the beginning of their entrepreneurship, yet they can still get great achievement so that we also consider it is not an essential factor. When we look into the explanation of entrepreneur's cognition, we find international orientation, sensitivity of opportunities, courage to overcome difficulties which was described by [33] and [34] are quite similar to entrepreneur's international vision and abilities, so we think the entrepreneur's ability can somehow cover this aspect.

From Table 1, we can see that the Chinese research about Born Globals' innovation culture and product or service are lacking. We infer that, in some terms, because most of the Chinese manufacturing Born Globals exist in traditional industries, which do not require high technology, and innovation thereby their products, can also not be considered as unique and competitive. Similarly, unique resources of Born Globals, which usually can be considered, come from their unique technology or knowledge, which are also related with innovation. Consequently, among the three factors we only found "innovation culture" and we infer it can cover most part of other two factors "products or service" and "unique resource".

To export-orientated manufacturing companies, international business is not independent while it needs the support from the investors, suppliers and distributors. Furthermore, many companies actually exist in international industrial chain, which makes the connection with their international partners more important. As a result, we also found international business network as one of the critical success factors. About the financial condition, we think for any international companies, enough capital support is always the guarantee of faster internationa-

\footnotetext{
${ }^{1}$ Industry Cluster: a cluster of related institutions or support institutions, which are geographically close to each other. They stay in the same specific industry and combined together because of the commonalities and complementarities. Usually these institutions conclude similar companies, upstream suppliers, downstream distributors and some financial and government institutions [27].
} 
lization so that we do not consider it as a typical Chinese Born Global's critical success international factor.

Mostly, Born Global's competitive strategies come from, for example, the low cost or unique products, which occupy big market, share of some niche markets. Obviously, due to China's low labor and material prices, most of the Chinese international companies but not only these Chinese manufacturing companies have the cost advantage. Though low cost is the main advantage of Chinese Born Globals' internationalization, we do not think this it is a very unique competitive advantage, which only belongs to Chinese, manufacturing Born Globals. Meanwhile, as we argue above, we found "innovation culture" as one of the critical success factors. Since the unique products also stem from the unique knowledge or innovation so that we believe "innovation culture" is enough to explain the competitive strategy in this aspect. Furthermore, for most of these Chinese Born Globals, how to use present resource or get more necessary resource to enter international market is essential during their internationalization. Overall, here we only found "market entry strategy" as critical international success factor from the strategic perspective.

As we indicated, Born Global phenomenon more happens in high-technology industries or the industries in growth stage [36]. Chinese manufacturing Born Globals more exist in traditional industries which are in mature stages so we infer that the influence of the factor "industry condition" may be not obvious. Industry cluster, which belongs to "geographic location", is emphasized in Chinese literature and many industry cluster areas have business history or culture since ancient time. A lot of export-orientated companies concentrate in some specific areas such as Zhejiang province and Guangdong Province where the industry cluster is obvious. We consider geographic location to be an essential success factor. There is no doubt that the influence on export enterprises from Chinese government is stronger than many other governments, so that the "government policies" should be incorporated in the critical success factors.

\section{Concluding Discussion}

This article contributes with a literature review that includes literature from both Western countries and China in both English and Chinese. In our work, we have identified success factors and categorized them in different themes. From these themes we develop a conceptual framework that is useful to understand different success factors in Chinese and Western Born Globals.

To conduct this research of Chinese literature written in Chinese, one of the researchers in this team is Chinese. Without this language, contextual and culture based literature, analysis could not have been done. One of our major observations in this research is that we have identified that most of the Chinese Born Globals publications about the internationalization success factors are based on the Western literature and use these as the theoretical platform in the design of their own research strategy and research questions design. The consequence of this observation is important as it indicates that Chinese researchers are reproducing research under different contextual and situational conditions that might lead to unclear conclusions or maybe even wrong conclusions. Furthermore, compared to most Western Born Global companies, which treat innovation as core competence, the innovation culture becomes one of the biggest weaknesses of Chinese manufacturing Born Globals' internationalization. China has special economic environment. Chinese manufacturing Born Globals not only need to follow the market but also the government policies, since the government greatly influences the industries and the whole economy. To foreign investors who want to exploit Chinese market, they also should take Chinese economic background and government policies into consideration.

One important aspect of Chinese born Globals, neglected in previous research on Born Globals, that has been identified in our research, is the critical success factor of Chinese manufacturing Born Globals - the political and economic background and the role of the Chinese Government in the transformation process of Chinese business life, and the Guanxi network. These factors are distinct factors, which affect Chinese Born Globals' internationalization.

\section{Acknowledgements}

We acknowledge the financial support from the Swedish Research Council and the KK-foundation.

\section{References}

[1] Wictor, I. (2006) Born Globals: Explanations to Rapid Internationalization. School of Business, Economics and Law, Gothenburg University, Gothenburg. 
[2] Andersson, S. and Wictor, I. (2003) Innovative Internationalization in New Firms: Born Global-The Swedish Case. Journal of International Entrepreneurship, 1, 249-275. http://dx.doi.org/10.1023/A:1024110806241

[3] Evers, N. (2010) Factors Influencing the Internationalization of New Ventures in the Irish Aquacultural Industry: An Exploratory Study. Journal of International Entrepreneurship, 8, 392-416. http://dx.doi.org/10.1007/s10843-010-0065-7

[4] Evers, N. (2011) International New Ventures in Low-Tech Sectors-A Dynamic Capabilities Perspective. Journal of Small Business \& Enterprise Development, 18, 502-528. http://dx.doi.org/10.1108/14626001111155682

[5] Andersson, S., Eriksson, M. and Lundmark, L. (2006) Internationalization in Malaysian Furniture Firms: Gradual or Rapid Internationalisation? International Journal of Globalization and Small Business, 1, 220-243. http://dx.doi.org/10.1504/IJGSB.2006.010609

[6] Johanson, J. and Wiedersheim-Paul, F. (1975) The Internationalization of the Firm-Four Swedish Cases. The Journal of Management Studies, 12, 305-323. http://dx.doi.org/10.1111/j.1467-6486.1975.tb00514.x

[7] Johanson, J. and Vahlne, J.E. (1977) The Internationalization Process of the Firm. Journal of International Business Studies, 8, 23-32. http://dx.doi.org/10.1057/palgrave.jibs.8490676

[8] Hashai, N. and Almor, T. (2004) Gradually Internationalizing “Born Global” Firms: An Oxymoron? International Business Review, 13, 465-483. http://dx.doi.org/10.1016/j.ibusrev.2004.04.004

[9] Moen, O. and Servais, P. (2002) Born Global or Gradual Global? Examinaing the Export Behavior of Small and Medium-Sized Enterprises. Journal of International Marketing, 10, 49-72. http://dx.doi.org/10.1509/jimk.10.3.49.19540

[10] Andersson, S. (2000) The Internationalization of the Firm from an Entrepreneurial Perspective. International Studies of Management and Organization, 30, 63-92.

[11] Madsen, T.K. and Servais, P. (1997) The Internationalization of Born Globals: An Evolutionary Process? International Business Review, 6, 561-583. http://dx.doi.org/10.1016/S0969-5931(97)00032-2

[12] Oviatt, B.M. and McDougall, P.P. (1994) Toward a Theory of International New Ventures. Journal of International Business Studies, 25, 45-64. http://dx.doi.org/10.1057/palgrave.jibs.8490193

[13] Knight, G.A. and Cavusgil, S.T. (1996) The Born Global Firm: A Challenge to Traditional Internationalization Theory. Advances in International Marketing, 8, 11-26.

[14] Oviatt, B.M. and McDougall, P.P. (1999) A Framework for Understanding Accelerated International Entrepreneurship. In: Wright, R., Ed., Research in Global Strategic Management: International Entrepreneurship, JAI Press, Stamford, 23-40.

[15] Crick, D. and Jones, M.V. (2000) Small High-Technology Firms and International High-Technology Markets. Journal of International Marketing, 8, 63-85. http://dx.doi.org/10.1509/jimk.8.2.63.19623

[16] Malhorta, N.K. (2001) Pesquisa de marketing, uma orientacäo aplicada. 3rd Edition, Bookman, Porto Alegre.

[17] Gummesson, E. (2002) Total Relationship Marketing: Marketing Management, Relationship Strategy and CRM Approaches for the Network Economy. 2nd Edition, Butterworth-Heinemann, Oxford.

[18] Andersen, O. (1993) On the Internationalization Process of Firms: A Critical Analysis. Journal of International Business Studies, 24, 209-231. http://dx.doi.org/10.1057/palgrave.jibs.8490230

[19] Rasmussen, E.S. and Madsen, T.K. (2002) The Born Global Concept. The 28th EIBA Conference 2002, University of Southern Denmark, Athens, 8-10 December 2002.

[20] Anon (2011) The Reform and Opening-Up Policy. http://baike.baidu.com/view/48598.htm\#sub48598

[21] Zhu, J.Q. (2008) The Growth Mechanism of International New Venture. PhD Thesis, Fudan University, Shanghai.

[22] Li, C. and Zhou, Y. (2009) Driver to the Formation of INV: The Case of Four Zhejiang SMEs. Journal of Management Case Studies, 2, 180-193.

[23] Rialp, A., Rialp, J., Urbana, D. and Vaillant, Y. (2005) The Born-Global Phenomenon: A Comparative Case Study Research. Journal of International Entrepreneurship, 3, 133-171. http://dx.doi.org/10.1007/s10843-005-4202-7

[24] Fang, T. (1999) Chinese Business Negotiating Style. Sage, Thousand Oaks.

[25] Helgesson, T. (1996) Culture in International Business-An Introduction. Academia Adacta AB, Lund, Sweden.

[26] Chen, M.J. (2001) Inside Chinese Business: A Guide for Managers Worldwide. Harvard Business School Press, Boston.

[27] Ye, J. (2009) Born Globals and the Impact of the Cluster Mechanism: Analysis Based on the SMEs in NingBo. Master Thesis, East China Normal University, Shanghai.

[28] Zou, G. (2007) The Research on SMEs’ Internationalization in Zhejiang Province. PhD Thesis, Zhejiang University, 
Hangzhou.

[29] Oviatt, B.M. and McDougall, P.P. (1995) Global Starts-Ups: Entrepreneurs on a Worldwide Stage. The Academy of Management Executive, 9, 30-44.

[30] Persinger, E.S., Civi, E. and Vostina, S.W. (2007) The Born Global Entrepreneurs in Emerging Economies. International Business and Economics Research Journal, 6, 73-82.

[31] Andersson, S. and Evangelista, F. (2006) The Entrepreneur in the Born Global Firm in Australia and Sweden. Journal of Small Business and Enterprise Development, 13, 642-659. http://dx.doi.org/10.1108/14626000610705796

[32] Knight, G.A. and Cavusgil, S.T. (2004) Innovation, Organizational Capabilities, and the Born Global Firm. Journal of International Business Studies, 35, 124-141. http://dx.doi.org/10.1057/palgrave.jibs.8400071

[33] Acedo, F.J. and Jones, M.V. (2007) Speed of Internationalization and Entrepreneurial Cognition: Insights and a Comparison between International New Ventures, Exporters and Domestic Firms. Journal of World Business, 42, $236-252$. http://dx.doi.org/10.1016/j.jwb.2007.04.012

[34] Chu, C.C. (2010) The Growth Process of International New Ventures Base on the Entrepreneurship. PhD Thesis, Anhui University, Hefei.

[35] Zhu, J.Q. (2010) Research on the Driving Forces of New Ventures Internationalization-from the Entrepreneur Perspective. Shanghai Management Science, 32, 13-17.

[36] Andersson, S. (2004) Internationalization in Different Industrial Contexts. Journal of Business Venturing, 19, $851-875$. http://dx.doi.org/10.1016/j.jbusvent.2003.10.002

[37] Oviatt, B.M. and McDougall, P.P. (1997) Challenges for Internationalization Process: The Case of International New Venture. Management International Review, 37, 85-99.

[38] Autio, E., Sapienza, H.J. and Almeida, J.G. (2000) Effects of Age at Entry, Knowledge Intensity, and Imitability on International Growth. Academy of Management Journal, 43, 909-924. http://dx.doi.org/10.2307/1556419

[39] Fernhaber, S.A., Oviatt, P.P. and McDougall, B.M. (2007) Exploring the Role of Industry Structure in New Venture Internationalization. Entrepreneurship Theory and Practice, 31, 517-542. http://dx.doi.org/10.1111/j.1540-6520.2007.00186.x

[40] Fernhaber, S.A., Gilbert, B.A. and McDougall, P.P. (2008) International Entrepreneurship and Geographic Location: An Empirical Examination of New Venture Internationalization. Journal of International Business Studies, 39, $267-$ 290. http://dx.doi.org/10.1057/palgrave.jibs.8400342

[41] Xue, Q.Z. and Zhou, J. (2007) The Formulation Mechanism of International New Venture's Competitive Advantage. Foreign Economics and Management, 29, 1-8.

[42] Yang, Z., Zhang, J., Chen, Y. and Liao, W.Y. (2007) Research on the Factors Which Push the Born Globals Development. Management World, 2, 122-136.

[43] Zahra, S.A. and George, G. (2002) International Entrepreneurship: The Current Status of the Field and Future Research Agenda. In: Hitt, M.A., Ireland, R.D. and Camp, S.M., Eds., Strategic Entrepreneurship: Creating a New Mindset, Blackwell Publisher, Oxford, 255-288.

[44] Burgel, O., Murray, G.C., Fier, A., Licht, G. and Nerlinger, E. (1998) The Internationalization of British and German Start-Up Companies in High-Technology Industries. Journal of International Marketing, 8, 33-62.

[45] McDougall, P.P. (1989) International versus Domestic Entrepreneurship: New Venture Strategic Behavior and Industry Structure. Journal of Business Venturing, 4, 387-400. http://dx.doi.org/10.1016/0883-9026(89)90009-8

[46] Zucchella, A., Palamara, G. and Denicolai, S. (2007) The Drivers of the Early Internationalization of the Firm. Journal of World Business, 42, 268-280. http://dx.doi.org/10.1016/j.jwb.2007.04.008

[47] Chen, X., Hu, Z.H. and Zhao, P. (2009) Characteristics and Driving Forces of Chinese Born Globals_Evidence from Comparative Studies of Four SMEs Case. China Soft Science, 4, 125-139.

[48] Shen, J. (2010) The Study of Small and Medium Sized Firms’ Internationalization Choices Based on International New Venture Theories. Journal of Hunan Financial and Economics College, 26, 124-127.

[49] Zhu, J.Q. (2009) Research on the International New Venture’s Growth under Multi-Theoretical Perspectives. Foreign Economics and Management, 31, 59-64.

[50] Lewin, M., Massini, A.Y. and Greve, H.R. (2005) Innovators and Imitators: Organizational Reference Groups and Adoption of Organizational Routines. Research Policy, 34, 1550-1569. http://dx.doi.org/10.1016/j.respol.2005.07.004 